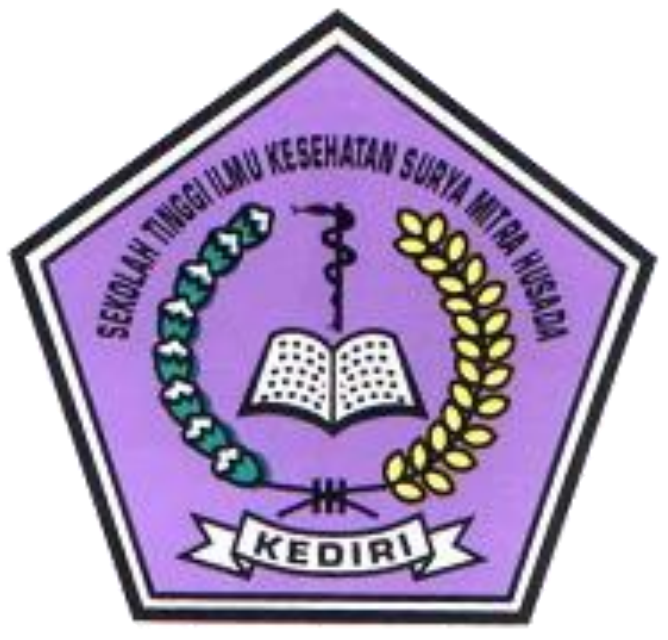

PROPOSAL PROGRAM KREATIVITAS MAHASISWA EFEKTIVITAS DAUN WARU (HIBISCUS TILIACEUS) SEBAGAI ALTERNATIF DETERGEN YANG RAMAH LINGKUNGAN

\title{
BIDANG KEGIATAN
}

PKM PENELITIAN

\begin{tabular}{llll}
\multicolumn{4}{c}{ Disusulkan oleh: } \\
(Ketua) & Leonardo Luciano Adolf & $1821 \mathrm{~B} 0019$ & Tahun Angkatan 2018 \\
(Anggota 1) & Putri Solehana Pertiwi & $1821 \mathrm{~B} 0023$ & Tahun Angkatan 2018 \\
(Anggota 2) & Yosephina Maria Cinta & $1821 \mathrm{~B} 0032$ & Tahun Angkatan 2018
\end{tabular}

STIKes SURYA MITRA HUSADA

KEDIRI 


\section{PENGESAHAN USULAN PKM PENELITIAN EKSAKTA}

\section{Judul Kegiatan}

\section{Bídang Kegiatan}

\section{Ketua Pelaksana Kegiatan}

a. Nama Lengkap

b. NIM

c. Program Studi

d. Perguruan Tinggi

e. Alamat Rumah dan No Tel./HP

f. Alamat email

4. Anggota Pelaksana Kegiatan/Penulis

5. Dosen Pendamping
a. Nama Lengkap dan Gelar
b. NIDN
c. Alamat Rumah dan No Tel./HP

\section{Biaya Kegiatan Total}

a. Dikti

b. Sumber lain (sebutkan...)

7. Jangka Waktu Pelaksanaan
: EFEKTIVITAS DAUN WARU (HIBISCUS TILIACEUS) SEBAGAI ALTERNATIF DETERGEN YANG RAMAH LINGKUNGAN

: PKMPE - Kesehatan

: leonardo luciano adolf

: 182180019

: S1 Ilmu Kesehatan Masyarakat

: STIKES Surya Mitra Husada

: Pogotena, Kota Tambolaka, Sumba Barat Daya, NTT, telp. 082338493213, hp. 082338493213

: Ronaladolf75@gmail.com

: 2 orang

: Dr NURWIJAYANTI S.Pd, M.Kes

: 0704017601

: Perum Tirtoudan Permai A-30 Tosaren Pesantren Kediri, telp. , hp. 085235954208

: Rp 10,325,000

: Rp 0; Sumber lain:

: 3 bulan.

Kediri, 8 - 1 - 2019
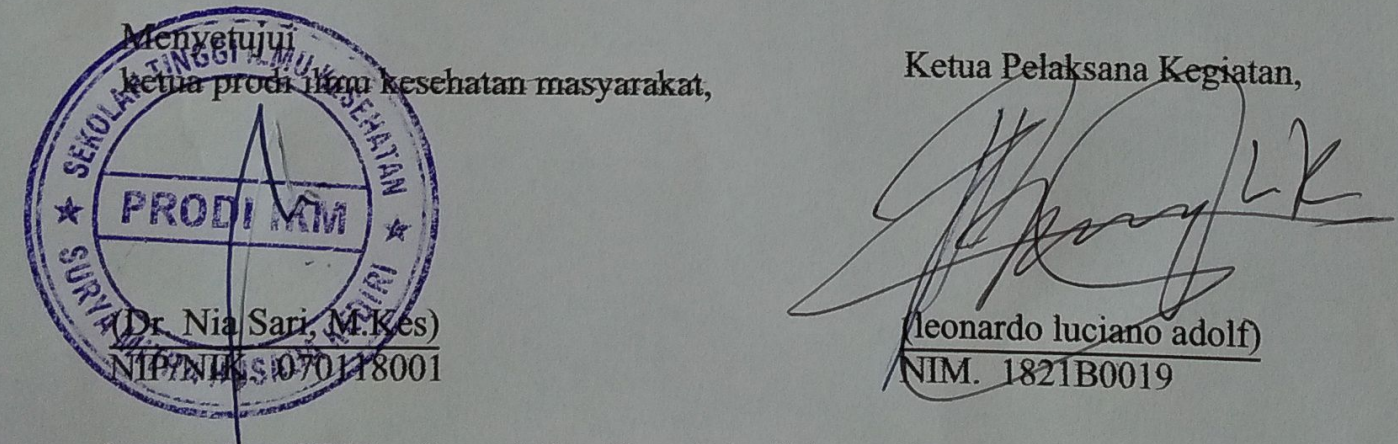

ketua stikes STIKes Surya Mitra Husada kediri,

Dosen Pendamping,
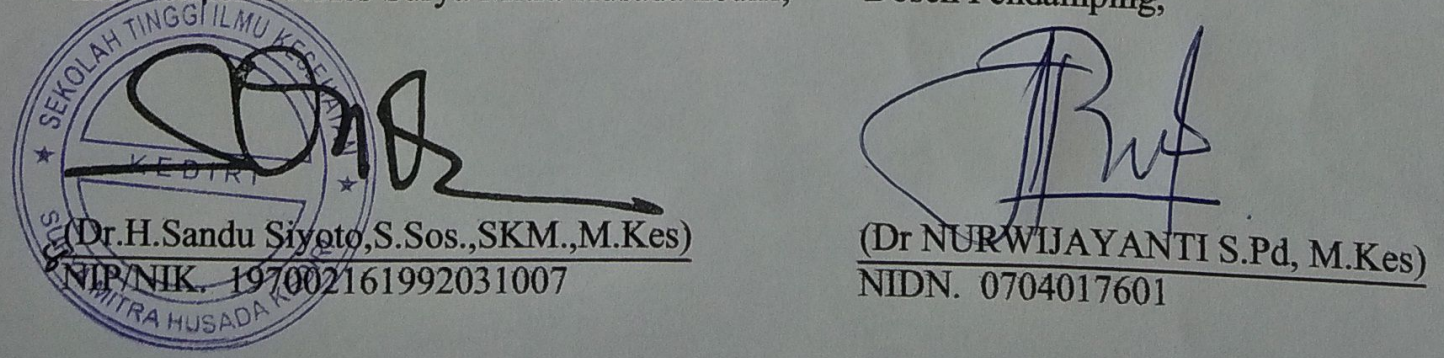


\section{DAFTAR ISI}

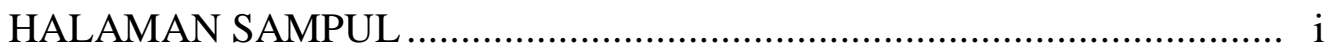

HALAMAN PENGESAHAN …..................................................... ii

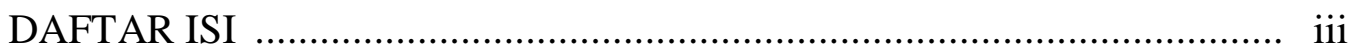

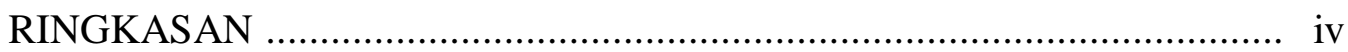

BAB I PENDAHULUAN ............................................................ 1

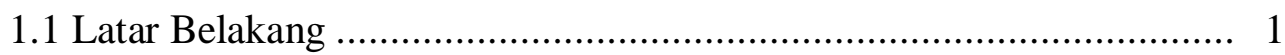

1.2 Rumusan Masalah .................................................................. 2

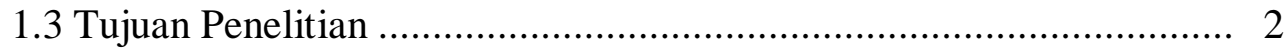

1.4 Urgensi Penelitian ....................................................................... 3

1.5 Luaran Yang Diharapkan........................................................... 3

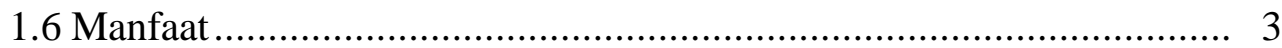

BAB II TINJAUAN PUSTAKA …............................................... 4

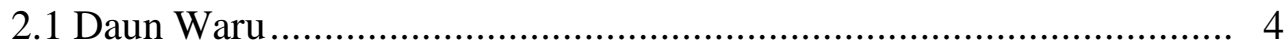

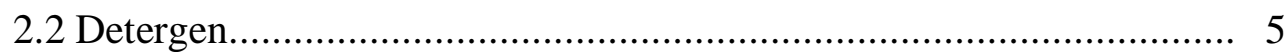

BAB III METODE PENELITIAN _..................................................... 6

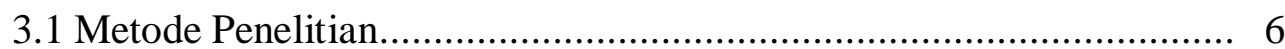

3.2 Desain Penelitian.................................................................. 6

3.3 Alat dan Bahan .......................................................................... 6

3.4 Metode Pelaksanaan .............................................................. 6

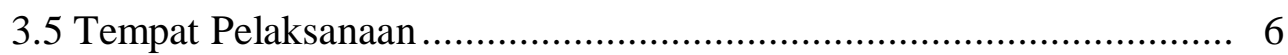

BAB IV BIAYA DAN JADWAL KEGIATAN ...................................... 7

4.1 Anggaran Biaya.......................................................................... 7

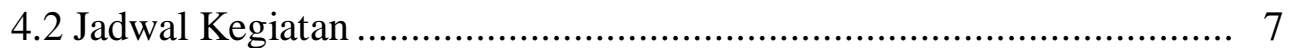

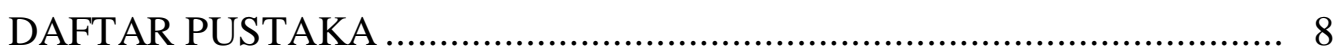

LAMPIRAN ........................................................................... 9

5.1 Biodata Ketua, Anggota, dan Dosen Pembimbing ............................ 9

5.2 Justifikasi Anggaran Kegiatan .................................................... 16

5.3 Susunan Organisasi Tim Penelitian dan Pembagian Tugas ............... 18

5.4 Surat Pernyataan Ketua Peneliti....................................................... 19 


\section{RINGKASAN}

Dengan banyaknya penggunaan detergen sintetis megakibatkan pencemaran air yang semakin meningkat. Karena detergen sintetis mengandung berbagai bahan kimia yang berbahaya diantaranya Alkyl Benzene Sulphonat (ABS) yang merupakan senyawa organik dengan rantai hidrokarbon yang panjang dan bercabang dengan cincin benzene pada ujungnya, yang dapat menyebabkan kesulitan bagi mikroorganisme untuk menguraikan unsur tersebut.

Berdasarkan kenyataan di atas, penulis selaku peneliti ingin melakukan eksperimen dengan memanfaatkan daun waru (hibiscus tiliaceus L.) sebagai alternatif detergen yang ramah lingkungan yang memiliki kandungan diantaranya busa (saponin) yang bertindak sebagai antiseptik.

Penelitian ini menggunakan metode kuantitatif yaitu metode eksperimen. Hasil eksperimen membuktikan bahwa daun waru (hibiscus tiliaceus L.) dapat dijadikan sebagai alternatif detergen yang ramah lingkungan karena setelah diuji, kandungan yang terdapat pada daun waru (hibiscus tiliaceus L.) bisa mematikan mikroba.

Penelitian ini diharapkan dapat memberikan informasi kepada masyarakat bahwa sebenarnya alam telah menyediakan bahan alami untuk membuat sesuatu yang aman digunakan. Misalnya daun waru (hibiscus tiliaceus) digunakan sebagai alternatif detergen yang ramah lingkungan.

Kata Kunci: Alkyl Benzene Sulphonat (ABS), daun waru (hibiscus tiliaceus), mikroba 


\section{BAB I}

\section{PENDAHULUAN}

\subsection{Latar Belakang}

Dengan semakin meningkatnya pemakaian bahan detergent kimia oleh masyarakat atau industry, maka semakin meningkat pula potensi pencemaran yang diakibatkan oleh sisa pembuangan yang mengandung detergen kimia tersebut. Keberadaan detergen dalam air semakin meningkat dari ambang batas yang telah ditentukan sehingga akan mengakibatkan menurunnya kualitas air, yang pada akhirnya akan berakibat pada kualitas kesehatan masyarakat (Santi, 2009).

Bahan - bahan pencemar badan air sangat banyak jumlahnya antara lain, detergen dalam hal ini Alkyl Benzene Sulphonat yaitu salah satu surfaktan yang banyak dipakai dalam bentuk bahan detergen. Senyawa ABS (Alkyl Benzene Sulphonat) merupakan senyawa organic dengan rantai hidrokarbon yang panjang dan bercabang dengan cincin benzene pada ujungnya, yang dapat menyebabkan kesulitan bagi mikroorganisme untuk menguraikan unsur tersebut (Santi, 2009). Bahan tersebut digunakan untuk memudahkan mengikat kotoran dan menimbulkan busa. Tentu busa-busa yang dihasilkan detergen tersebut memiliki dampak yang kurang baik terhadap lingkungan di sekitarnya.

Dampak dari adanya limbah deterjen di perairan yaitu terjadinya eutrofikasi oleh karena adanya senyawa fosfat dari deterjen yang menyebabkan tanaman perairan menjadi subur dan pertumbuhan alga menjadi meningkat melebihi batas normal atau biasa disebut dengan blooming (Suastuti, Suarsa and Putra, 2015).

Dalam hal lain senyawa-senyawa yang terkandung di dalam detergen dapat menimbulkan gangguan kesehatan terhadap manusia seperti iritasi pada kulit, penyebab katarak pada mata orang dewasa dan menimbulkan gangguan terhadap lingkungan seperti adanya busa-busa pada permukaan air sehingga mengurangi kadar oksigen terlarut dalam air (Sugiharto, 1987).

"Pohon waru (Hibiscus Tiliance L) termasuk dalam suku Malcaceae. Tumbuhan tropis berbatang sedang ini bisa tumbuh dipinggir jalan sebagai perindang maupun didekat pesisir atau lading. Daun waru merupakan salah satu daun yang memiliki kandung zat aktif tinggi berupa saponin, flavonoida, fenol dan tanin" (Pujo, 2009). 
Saponin terdiri dari sebuah steroid atau triterpenoid aglycone (sapogenin) yang terkait dengan satu atau lebih gugus oligosakarida. Adanya gugus polar (gula) dan non polar (steroid atau triterpene) membuat saponin memiliki permukaan aktif yang kuat yang memberikan banyak manfaat (Makkar, Siddhuraju and Becker, 2007). Fitokimia ini disebut demikian karena mereka kemampuan untuk membentuk busa seperti sabun yang stabil dalam larutan berair (Francis et al., 2002).

Untuk kelebihan lain daun waru dibandingkan dengan sabun atau detergen sintetis adalah lebih ekologis dan ekonomis. Limbah daun waru dapat diuraikan oleh alam dan tingkat pencemarannya hampir tidak ada. Air bekas mencuci bisa digunakan untuk menyiram tanaman. Jadi, mencuci menggunakan daun waru dapat mengurangi pemborosan penggunaan air.

\subsection{Rumusan Masalah}

Berdasarkan latar belakang di atas maka dapat dirumuskan sebagai berikut: Bagaimana efektivitas penggunakan daun waru (hibiscus tiliaceus) sebagai alternatif detergen yang ramah lingkungan?

\subsection{Tujuan Penelitian}

\subsubsection{Tujuan Umum}

Penelitian ini bertujuan untuk :

Mengetahui efektivitas penggunakan daun waru (hibiscus tiliaceus) sebagai alternatif detergen yang ramah lingkungan?

\subsubsection{Tujuan khusus}

1. Mengidentifikasi komposisi daun waru sebagai detergen pada konsentrasi $25 \%$ terhadap daya hambat bakteri Staphyloccocus aureus.

2. Mengidentrifikasi komposisi daun waru sebagai detergen pada konsentrasi 50\% terhadap daya hambat bakteri Staphyloccocus aureus.

3. Mengidentrifikasi komposisi daun waru sebagai detergen pada konsentrasi $75 \%$ terhadap daya hambat bakteri Staphyloccocus aureus.

4. Mengidentrifikasi komposisi daun waru sebagai detergen pada konsentrasi $100 \%$ terhadap daya hambat bakteri Staphyloccocus aureus.

5. Menganalisis berbagai konsentrasi daun waru terhadap daya hambat bakteri Staphylococcus aureus. 


\subsection{Urgensi Penelitian}

Penelitian ini penting dilakukan karena untuk mengatasi masalah lingkungan yaitu mengurangi dampak buruk pemakaian detergen sintetis dengan dibuatnya alternatif lain yaitu pembuatan detergen ramah lingkungan dengan memanfaatkan daun waru (hibiscus tiliaceus).

\subsection{Luaran yang Diharapkan}

Luaran yang diharapkan dalam penelitian publikasi jurnal Nasional ber ISSN dan buku cetak berISBN

\subsection{Manfaat Penelitian}

a. Bagi Pusat Layanan Kesehatan

1) Sebagai alternatif detergen yang ramah lingkungan.

2) Memberikan informasi tentang kandungan-kandungan yang ada di daun waru.

b. Institusi Pendidikan

1) Menambah pengetahuan bagi peneliti tentang pemanfaat daun waru (hibiscus tiliaceus) sebagai detergen yang ramah lingkungan.

2) Menerapkan ilmu yang telah didapatkan selama menjalani pendidikan.

3) Mengetahui adanya efek antibakteri daun waru (hibiscus tiliaceus) terhadap pertumbuhan bakteri Staphylococcus aureus.

c. Masyarakat

1) Memberikan informasi kepada masyarakat bahwa sebenarnya alam telah menyediakan bahan alami untuk membuat sesuatu yang aman digunakan. Misalnya daun waru (hibiscus tiliaceus) digunakan sebagai alternatif detergen yang ramah lingkungan.

2) Memberikan informasi kepada masyarakat tentang cara pengolahan daun waru menjadi detergen yang ramah lingkungan.

3) Memberikan informasi tentang manfaat daun waru dalam menghambat pertunbuhan bakteri Staphylococcus aerus.

4) Meningkatkan pemanfaatan daun waru (hibiscus tiliaceus) sebagai detergen yang ramah lingkungan. 


\section{BAB II \\ TINJAUAN PUSTAKA}

\subsection{Daun Waru}

Secara umum pengklasifikasian tanaman waru (Hibiscus tiliaceus L.) adalah sebagai berikut :

Divisi: Spermatophyta

Subdivisi: Angiospermae

Kelas: Dikotyledonae

Bangsa: Malvales

Suku: Malvaceae

Marga: Hibiscus

Jenis: Hibiscus tiliaceus L. (Syamsuhidayat and Hutapea, 1991)

Waru (Hibiscus tiliaceus) termasuk pada suku kapas-kapasan (Malvaceae), juga dikenal sebagai Waru Laut, atau Dadap Laut (Pontianak). Tumbuhan jenis ini telah lama dikenal sebagai pohon peneduh baik di tepi jalan atau di tepi sungai dan pematang serta di tepi pantai. Waru disukai karena akarnya tidak dalam sehingga tidak merusak jalan dan bangunan di sekitarnya, selain itu bunganya yang kuning mencolok indah dipandang mata. Waru yang masih semarga dengan kembang sepatu ini merupakan tumbuhan asli dari daerah tropika di daerah Pasifik Barat. Namun saat ini telah tersebar luas di seluruh wilayah Pasifik dan dikenal dengan berbagai nama: hau (bahasa Hawaii), purau (bahasa Tahiti), beach Hibiscus, Tewalpin, Sea Hibiscus, atau Coastal Cottonwood dalam bahasa Inggris.

Tumbuhan daerah tropis ini dapat tumbuh pada berbagai kondisi tanah, di daerah yang subur, batangnya lurus, namun pada tanah yang kurang subur batangnya cenderung tumbuh membengkok, serta percabangan dan daun-daunnya lebih lebar. Pohon waru bisa mencapai tinggi 5-15 m. Batangnya berkayu, bulat, bercabang banyak, warnanya cokelat. Daun bertangkai, tunggal, serta berbentuk jantung dengan diameter sekitar $19 \mathrm{~cm}$. Pertulangan menjari dan warnanya hijau. Pada bagian bawah daun berambut abu-abu rapat. Bunganya berdiri sendiri atau 2-5 di dalam tandan, dengan 8-11 buah tajuk, berwarna kuning disertai dengan noda ungu pada pangkal mahkota bagian dalam, dan akan berubah menjadi kuning merah, kemudian menjadi kemerah-merahan (S.Hut and Hendrati, 2014).

\subsubsection{Komposisi Daun Waru}

Daun waru memiliki kandungan senyawa saponin, flavonoid, polifenol dan tannin (Kinho et al., 2011).

Daun dan batang tanaman waru diketahui mengandung zat musilago yang sifatnya berfungsi untuk melapisi dinding saluran cerna, saluran kencing serta tenggorokan. Sementara zat yang lain yakni emolien bermanfaat sebagai pembasmi kuman (anti septik). Tanaman waru diketahui juga mengandung protein serta zat tanin. Nenek moyang kita telah menggunakan tanaman waru sebagai 
obat-obatan tradisional untuk menjaga kesehatan. Ada beberapa penyakit yang bisa disembuhkan oleh daun waru, dan diantaranya adalah penyakit batuk serta demam. Sementara itu kayu Waru banyak dimanfaatkan untuk pembuatan ukiran sebagai cindera mata (S.Hut and Hendrati, 2014).

\subsection{Detergen}

Detergen adalah salah satu produk komersial yang digunakan untuk menghilangkan kotoran pada pencucian pakaian. Dalam detergen mengandung bahan yang mempunyai sifat aktif permukaan (surfaktan). Surfaktan ini digunakan untuk proses pembahasan dan pengikat kotoran, sehingga sifat dari detergen dapat berbeda tergantung jenis surfaktannya (Kirk and Othmer, 1982).

Detergen umumnya tersusun atas tiga komponen utama yaitu, surfaktan sebagai bahan dasar detergen) yang berkisar antara 22-30\%, bahan builders (senyawa posfat) dan bahan aditif (pemutih dan pewangi). Surfaktan merupakan molekul yang memiliki gugus polar yang suka air (hidrofilik) dan gugus non polar yang suka minyak (lipofilik) sekaligus, sehingga dapat mempersatukan campuran yang terdiri dari minyak dan air. Surfaktan pada umumnya disintesis dari turunan minyak bumi dan limbahnya dapat mencemarkan lingkungan,karena sifatnya yang sukar terdegradasi (Purnamasari, 2014).

Bahan surfaktan yang biasa digunakan adalah alkyl benzene (ABS). Senyawa ini termasuk dalam senyawa non biodegradable yaitu tidak dapat didegradasi oleh mikroorganisme, dan juga banyak menimbulkan busa baik pada sungai ataupun air tanah sehingga senyawa tersebut diganti dengan linear alkyl sulphonat (LAS) yang lebih mudah didegradasi (Santi, 2009).

Adapun efek yang dapat ditimbulkan oleh adanya detergen dalam air antara lain yaitu terbentuknya film akan menyebabkan menurunnya tingkat transfer ke dalam air, pada konsentrasi yang melebihi ambang batas yang ditentukan, dapat menyebabkan gangguan kesehatan yang cukup serius, kombinasi antara polyphospat dengan surfaktan dalam detergen dapat mempertinngi kandungan phospat dalam air. Hal ini akan menyebabkan terjadinya entroikasi yang dapat menimbulkan warna pada air (Santi, 2009). Eutrofikasi karena adanya senyawa fosfat dari deterjen juga dapat menyebabkan tanaman perairan menjadi subur dan pertumbuhan alga menjadi meningkat melebihi batas normal atau biasa disebut dengan blooming (Suastuti, Suarsa and Putra, 2015). 


\section{BAB III \\ METODE PENELITIAN}

\subsection{Metode Penelitian}

Metode penelitian yang digunakan dalam penelitian ini adalah menggunakan metode penelitian eksperimen (Metode Kuantitatif).

"Metode penelitian eksperimen merupakan metode penelitian yang digunakan untuk mencari pengaruh treatment (perlakuan) tertentu" (Sugiyono, 2010).

\subsection{Desain Penelitian}

Jenis penelitian ini adalah Eksperimantali dengan rancangan Acak Kelompok (RAK).

\subsection{Alat dan Bahan}

a. Biakan murni bakteri Staphylococcus aureus dalam media nutrient cair yang berumur 24 jam.

b. Media lempeng nutrient agar (NA) steril.

c. Berbagai zat antiseptic: betadine, sabun yang mengandung antiseptic, iodium, wipol

d. Paper disc

e. Cotton buds

\subsection{Metode Pelaksanaan}

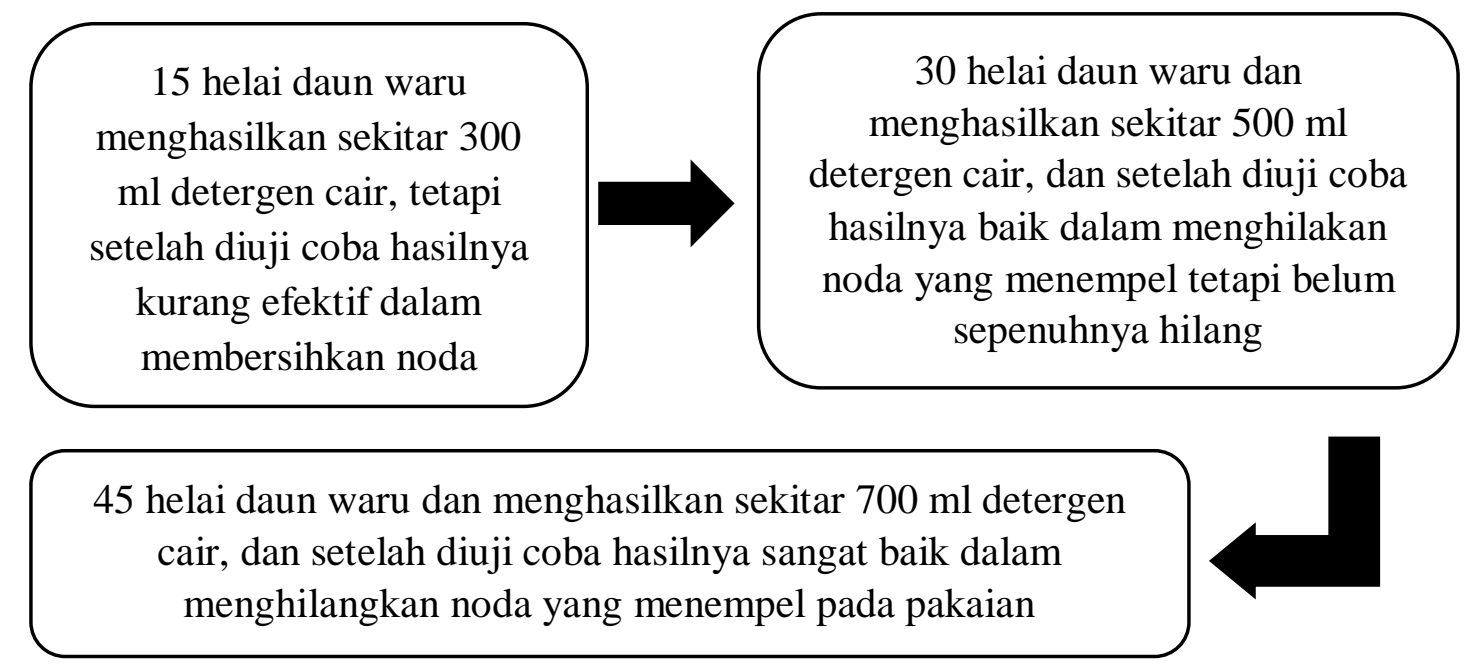

\subsection{Tempat Pelaksanaan}

Proses pelaksanaan pembuatan detergen ramah lingkungan dilakukan di laboratorium STIKes Surya Mitra Husada Kediri. 
BAB IV

BIAYA DAN JADWAL KEGIATAN

1.1 Anggaran Biaya

\begin{tabular}{|c|c|c|}
\hline No & Jenis Pengeluaran & Biaya \\
\hline 1 & Perlengkapan Yang Diperlukan & $\operatorname{Rp} 4.180 .000$ \\
\hline 2 & Bahan Habis Pakai & $\operatorname{Rp} 2.045 .000$ \\
\hline 3 & Pejalanan & Rp 3.000.000 \\
\hline 4 & Lain-lain & Rp 1.100 .000 \\
\hline & Jumlah & Rp 10.325.000 \\
\hline
\end{tabular}

1.2 Jadwal Kegiatan

\begin{tabular}{|c|l|c|c|c|c|c|}
\hline \multirow{2}{*}{ No } & \multicolumn{5}{|c|}{ Kegiatan } & \multicolumn{5}{c|}{ Bulan } \\
\cline { 3 - 7 } & & 1 & 2 & 3 & 4 & 5 \\
\hline 1 & Pencarian materi untuk penelitian & & & & & \\
\hline 2 & Pencarian bahan-bahan untuk diteliti & & & & & \\
\hline 3 & Konsultasi tentang penelitian & & & & & \\
\hline 4 & Evaluasi & & & & & \\
\hline
\end{tabular}




\section{DAFTAR PUSTAKA}

Francis, G. et al. (2002) 'The Biological Action of Saponins in Animal Systems : a Review', British Journal of Nutrition, 88(2002), pp. 587-605. doi: 10.1079/BJN2002725.

Kinho, J. et al. (2011) Tumbuhan Obat Tradisional di Sulawesi Utara.

Kirk, R. . and Othmer, D. . (1982) 'The Interscience and Encyclopedia Inc'.

Makkar, H. P. ., Siddhuraju, P. and Becker, K. (2007) Plant Secondary

Metabolites.

Netala, V. . et al. (2014) 'Triterpenoid Saponins: A Review on Biosynthesis, Aplications and Mechanism of Their Action', International Journal Pharmaci, 7 , pp. 24-28. doi: 10.3390/molecules21101404.

Pujo, S. (2009) Tumbuhan Berkhasiat Obat.

Purnamasari, E. N. (2014) 'Karakteristik Kandungan Linear Alkyl Benzene

Sulfonat (Las) pada Limbah Cair Laundry', Jurnal Media Teknik, 11(1), pp. 3236.

S.Hut, S. and Hendrati, R. L. (2014) Perbanyakan Vegetatif dan Penanaman Waru (Hibiscus Tiliaceus).

Santi, S. S. (2009) 'Penurunan Konsentrasi Surfactan pada Limbah Detergen dengan Proses Photokatalitik Sinar UV', Jurnal Teknik Kimia, 4(1), pp. 260-264. Suastuti, D. A., Suarsa, I. W. and Putra, D. K. (2015) 'Pengolahan Larutan Detergen dengan Biofilter Tanaman Kangkungan (Ipomoea Crassicaulis) dalam Sistem Batch (Curah) Teraerasi', Jurnal Kimia FMIPA, 9(1), pp. 98-104.

Sugiharto (1987) Dasar - Dasar Pengelolaan Air Limbah.

Sugiyono (2010) Metode Penelitian Kuantitatif Kualitatif.

Syamsuhidayat, S. . and Hutapea, J. . (1991) Inventaris Tanaman Obat Indonesia I. 


\section{LAMPIRAN-LAMPIRAN}

\section{Lampiran 1. Biodata Ketua, Anggota dan Dosen Pembimbing}

\section{A. Identitas Diri}

\begin{tabular}{|c|l|l|}
\hline 1 & Nama Lengkap & Leonardo Luciano Adolf \\
\hline 2 & Jenis Kelamin & Laki-Laki \\
\hline 3 & Program Studi & Ilmu Kesehatan Masyarakat \\
\hline 4 & NIM & 1821 B0019 \\
\hline 5 & Tempat dan Tanggal Lahir & Waliubannu, 26 Agustus 2000 \\
\hline 6 & Email & Ronaladolf75@gmail.com \\
\hline 7 & No. Telp. / HP & 082338493213 \\
\hline
\end{tabular}

\section{B. Kegiatan Kemahasiswaan Yang Pernah Diikui}

\begin{tabular}{|c|c|c|c|}
\hline No & Jenis Kegiatan & Status dalam Kegiatan & tu dan Tempat \\
\hline \multicolumn{4}{|c|}{ C. Penghargaan Yang Pernah Diterima } \\
\hline No & Jenis Penghargaan & Pihak Pemberi Penghargaan & Tahun \\
\hline
\end{tabular}

Semua data yang saya isikan dan tercantum dalam biodata ini adalah benar dan dapat dipertanggungjawabkan secara hukum. Apabila dikemudian hari ternyata dijumpai ketidaksesuaian dengan kenyataan, saya sanggup menerima sanksi. Demikian biodata ini saya buat dengan sebenarnya untuk memenuhi salah satu Persyaratan dalam pengajuan Hibah PKM Penelitian.

Kediri, 20 Desember 2018

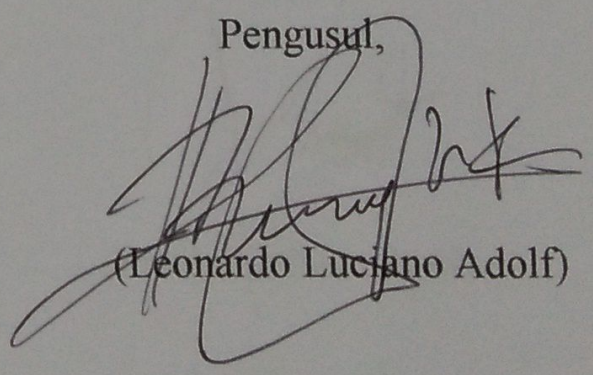




\section{Biodata Anggota 1}

D. Identitas Diri

\begin{tabular}{|c|l|l|}
\hline 1 & Nama Lengkap & Putri Solehana Pertiwi \\
\hline 2 & Jenis Kelamin & Perempuan \\
\hline 3 & Program Studi & Ilmu Kesehatan Masyarakat \\
\hline 4 & NIM & 1821 B0023 \\
\hline 5 & Tempat dan Tanggal Lahir & Trenggalek, 29 September 1999 \\
\hline 6 & Email & putri.solehanapertiwi@gmail.com \\
\hline 7 & No. Telp. / HP & 083111682019 \\
\hline
\end{tabular}

E. Kegiatan Kemahasiswaan Yang Pernah Diikui

\begin{tabular}{|l|l|l|l|}
\hline No & Jenis Kegiatan & Status dalam Kegiatan & Waktu dan Tempat \\
\hline
\end{tabular}

\section{F. Penghargaan Yang Pernah Diterima}

\begin{tabular}{|l|l|l|l|}
\hline No & Jenis Penghargaan & Pihak Pemberi Penghargaan & Tahun \\
\hline
\end{tabular}

Semua data yang saya isikan dan tercantum dalam biodata ini adalah benar dan dapat dipertanggungjawabkan secara hukum. Apabila dikemudian hari ternyata dijumpai ketidaksesuaian dengan kenyataan, saya sanggup menerima sanksi. Demikian biodata ini saya buat dengan sebenarnya untuk memenuhi salah satu Persyaratan dalam pengajuan Hibah PKM Penelitian.

Kediri, 20 Desember 2018

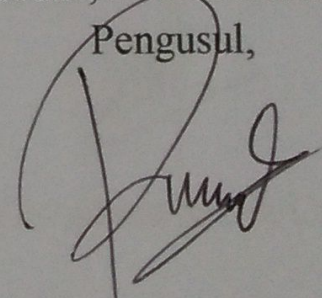

(Putri Solehana Pertiwi) 
Biodata Anggota 2

G. Identitas Diri

\begin{tabular}{|l|l|l|}
\hline 1 & Nama Lengkap & Yosephina Maria Cinta \\
\hline 2 & Jenis Kelamin & Perempuan \\
\hline 3 & Program Studi & Ilmu Kesehatan Masyarakat \\
\hline 4 & NIM & 1821 B0032 \\
\hline 5 & Tempat dan Tanggal Lahir & Wolowaru, 20 Maret 2000 \\
\hline 6 & Email & ursulacinta517@gmail.com \\
\hline 7 & No. Telp. / HP & 082247326365 \\
\hline
\end{tabular}

H. Kegiatan Kemahasiswaan Yang Pernah Diikui

\begin{tabular}{|l|l|l|l|}
\hline No & Jenis Kegiatan & Status dalam Kegiatan & Waktu dan Tempat \\
\hline
\end{tabular}

\section{Penghargaan Yang Pernah Diterima}

\begin{tabular}{|l|l|l|l|}
\hline No & Jenis Penghargaan & Pihak Pemberi Penghargaan & Tahun \\
\hline
\end{tabular}

Semua data yang saya isikan dan tercantum dalam biodata ini adalah benar dan dapat dipertanggungjawabkan secara hukum. Apabila dikemudian hari ternyata dijumpai ketidaksesuaian dengan kenyataan, saya sanggup menerima sanksi. Demikian biodata ini saya buat dengan sebenarnya untuk memenuhi salah satu Persyaratan dalam pengajuan Hibah PKM Penelitian.

Kediri, 20 Desember 2018

Pengusul,

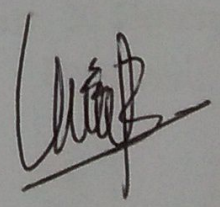

(Yosephina Maria Cinta) 
Biodata Dosen Pembimbing

A. Identitas Diri

\begin{tabular}{|l|l|l|}
\hline 1 & Nama Lengkap & DR Nurwijayanti,Spd.M.Kes \\
\hline 2 & Jenis Kelamin & Perempuan \\
\hline 3 & Program Studi & Ilmu Kesehatan Masyarakat \\
\hline 4 & NIDN & 0704017601 \\
\hline 5 & Tempat dan Tanggal Lahir & Yogyakarta,4 januari 1976 \\
\hline 6 & Alamat E-Mail & wijayantistikes @gmail.com \\
\hline 7 & Nomor Telepon/Hp & 085235954208 \\
\hline
\end{tabular}

B. Riwayat Pendidikan

\begin{tabular}{|l|l|l|l|}
\hline Gelar Akademik & \multicolumn{1}{|c|}{ S-1 } & \multicolumn{1}{c|}{ S-2 } & \multicolumn{1}{|c|}{ S-3 } \\
\hline Nama Institusi & $\begin{array}{l}\text { Universitas } \\
\text { Negeri } \\
\text { Malang }\end{array}$ & $\begin{array}{l}\text { Universitas } \\
\text { Airlangga } \\
\text { Surabaya }\end{array}$ & $\begin{array}{l}\text { Universitas } \\
\text { Brawijaya }\end{array}$ \\
\hline Jurusan/Prodi & $\begin{array}{l}\text { Pendidikan } \\
\text { Biologi }\end{array}$ & $\begin{array}{l}\text { Kesehatan } \\
\text { Masyarakat }\end{array}$ & Pertanian \\
\hline Tahun Masuk - Lulus & $1999-2001$ & 2007-2009 & $\mathbf{2 0 1 2 - 2 0 1 6}$ \\
\hline
\end{tabular}

C. Penelitian

\begin{tabular}{|l|l|l|l|l|}
\hline No & Tahun & \multicolumn{1}{|c|}{ Judul Penelitian } & \multicolumn{2}{|c|}{ Pendanaan } \\
\hline 1 & 2016 & $\begin{array}{l}\text { KETERKAITAN } \\
\text { KEKURANGAN } \\
\text { ENERGI PROTEIN } \\
\text { (KEP) DENGAN } \\
\text { KEJADIAN INFEKSI } \\
\text { SALURAN } \\
\text { PERNAFASAN AKUT } \\
\text { (ISPA) PADA BALITA } \\
\text { USIA (1-5 TAHUN) }\end{array}$ & $\begin{array}{l}\text { Mandiri } \\
\text { mahsama }\end{array}$ & Rp. 3.000.000,- \\
& & & \\
\hline
\end{tabular}




\begin{tabular}{|l|l|l|l|l|}
\hline 2 & 2017 & $\begin{array}{l}\text { HUBUNGAN } \\
\text { PERKEMBANGAN } \\
\text { BAHASA } \\
\text { STATUS GIZI ANAK } \\
\text { Di WILAYAH KERJA } \\
\text { PUSKESMAS } \\
\text { WILAYAH SELATAN } \\
\text { KOTA KEDIRI }\end{array}$ & $\begin{array}{l}\text { Mandiri } \\
\text { bersama } \\
\text { mahasiswa }\end{array}$ & Rp. 3.000.000,- \\
\hline $\mathbf{3}$ & 2018 & $\begin{array}{l}\text { Pola Makan,Kebiasaan } \\
\text { Sarapan dan Status } \\
\text { Gizi Berhubungan } \\
\text { Dengan Prestasi Belajar } \\
\text { Siswa SMK di Kota } \\
\text { Kediri }\end{array}$ & $\begin{array}{l}\text { Mandiri } \\
\text { bersama } \\
\text { mahasiswa }\end{array}$ & Rp. 3.000.000,- \\
\hline $\mathbf{4}$ & 2018 & $\begin{array}{l}\text { Analysis the Influence } \\
\text { of Taboo Food } \\
\text { Knowledge and } \\
\text { Compliance Consumes } \\
\text { Fe Tablets with Anemia } \\
\text { Incidence in Pregnant } \\
\text { Women at Pesantren 1 } \\
\text { Public Health Center } \\
\text { Kediri }\end{array}$ & $\begin{array}{l}\text { Mandiri } \\
\text { bersama } \\
\text { mahasiswa }\end{array}$ & Rp. 3.000.000,- \\
\hline
\end{tabular}

D. Pengabdian Kepada Masyarakat

\begin{tabular}{|l|l|l|l|l|}
\hline No & Tahun & $\begin{array}{c}\text { Judul Pengabdian } \\
\text { Kepada Masyarakat }\end{array}$ & \multicolumn{2}{|c|}{ Pendanaan } \\
\hline $\mathbf{1}$ & 2016 & $\begin{array}{l}\text { Pelatihan Baby sitter di } \\
\text { wilayah kota kediri } \\
\text { dalam rangka } \\
\text { penanganan remaja } \\
\text { putus sekolah melalui } \\
\text { program belajar } \\
\text { nonformal }\end{array}$ & $\begin{array}{l}\text { Departemen } \\
\text { Pendidikan } \\
\text { dan } \\
\text { Kebudayaan }\end{array}$ & $\begin{array}{l}\text { Rp. } \\
80.000 .000,-\end{array}$ \\
\hline $\mathbf{2}$ & 2017 & $\begin{array}{l}\text { Pelatihan Baby sitter di } \\
\text { perkampungan tuna }\end{array}$ & $\begin{array}{l}\text { Pemerintah } \\
\text { Kota Kediri }\end{array}$ & $\begin{array}{l}\text { Rp. } \\
30.000 .000,-\end{array}$ \\
\hline
\end{tabular}




\begin{tabular}{|l|l|l|l|l|}
\hline & & $\begin{array}{l}\text { wisma kelurahan } \\
\text { semampir kota Kediri }\end{array}$ & \\
\hline 3 & 2018 & $\begin{array}{l}\text { Pelatihan manajemen } \\
\text { laktasi bagi ibu } \\
\text { primigravida trimester } \\
\text { III sebagai upaya } \\
\text { peningkatan gizi balita } \\
\text { dan pencegahan angka } \\
\text { kematian bayi } \\
\text { diwilayah kerja } \\
\text { puskesmas kota Kediri }\end{array}$ & $\begin{array}{l}\text { Pemerintah } \\
\text { Kota Kediri }\end{array}$ & $\begin{array}{l}\text { Rp. } \\
20.000 .000,-\end{array}$ \\
& & & \\
& & & \\
\hline
\end{tabular}




\section{Lampiran 2. Justifikasi Anggaran Kegiatan}

\begin{tabular}{|c|c|c|c|}
\hline 1. Jenis Perlengkapan & Volume & Harga Satuan (Rp) & Jumlah (Rp) \\
\hline Baskom & 3 & 50.000 & 150.000 \\
\hline Mortar dan Alu & 3 & 500.000 & 1.500 .000 \\
\hline Kertas Saringan & 25 pack & 50.000 & 1.250 .000 \\
\hline Handscoon & 2 kardus & 50.000 & 100.000 \\
\hline Tabung Reaksi & 20 buah & 10.000 & 200.000 \\
\hline Pipet Tetes & 5 & 20.000 & 100.000 \\
\hline Map Plastik & 2 & 15.000 & 30.000 \\
\hline Kaca Pembesar & 1 & 100.000 & 100.000 \\
\hline Gelas ukur $500 \mathrm{cc}$ & 5 & 150.000 & 750.000 \\
\hline \multicolumn{3}{|r|}{ SUB TOTAL (Rp) } & 4.180 .000 \\
\hline 2. Bahan Habis Pakai & Volume & Harga Satuan (Rp) & Jumlah (Rp) \\
\hline Bibit Parfum & 5 & 200.000 & 1.000 .000 \\
\hline Air Bersih & 10 kali & 50.000 & 500.000 \\
\hline Daun Waru & $\begin{array}{c}500 \\
\text { lembar }\end{array}$ & 1000 & 500.000 \\
\hline Spidol Permanen & 2 & 15.000 & 30.000 \\
\hline Bolpoin & 3 & 5000 & 15.000 \\
\hline \multicolumn{3}{|r|}{ SUB TOTAL (Rp) } & 2.045 .000 \\
\hline 3. Perjalanan & Volume & Harga Satuan (Rp) & Jumlah (Rp) \\
\hline $\begin{array}{c}\text { Transportasi pencarian } \\
\text { daun waru }\end{array}$ & $\begin{array}{c}5 \text { kali } \\
\text { perjalanan }\end{array}$ & 150.000 & 750.000 \\
\hline Transportasi dalam kota & $\begin{array}{c}10 \\
\text { kali perjal } \\
\text { anan }\end{array}$ & 150.000 & 1.500 .000 \\
\hline
\end{tabular}




\begin{tabular}{|c|c|c|c|}
\hline $\begin{array}{c}\text { Transportasi Pencarian } \\
\text { Alat }\end{array}$ & $\begin{array}{c}5 \text { kali } \\
\text { perjalanan }\end{array}$ & 150.000 & 750.000 \\
\hline \multicolumn{3}{|c|}{ SUB TOTAL (Rp) } & 3.000 .000 \\
\hline 4. Lain-lain & Volume & Harga Satuan (Rp) & Jumlah (Rp) \\
\hline $\begin{array}{l}\text { Pembuatan Laporan dan } \\
\text { Jurnal Ilmiah }\end{array}$ & $\begin{array}{c}1 \\
\text { rangkaian } \\
\text { dari awal } \\
\text { sampai } \\
\text { akhir }\end{array}$ & 500.000 & 500.000 \\
\hline Konsumsi & $\begin{array}{c}20 \text { kali } \\
\text { pertemuan }\end{array}$ & 30.000 & 600.000 \\
\hline \multicolumn{3}{|r|}{ SUB TOTAL (Rp) } & 1.100 .000 \\
\hline \multicolumn{3}{|r|}{ TOTAL $1+2+3+4(\mathrm{Rp})$} & 10.325 .000 \\
\hline
\end{tabular}


Lampiran 3. Susunan Organisasi Tim Penelitian dan Pembagian Tugas

\begin{tabular}{|c|c|c|c|c|c|}
\hline No & $\begin{array}{c}\text { Nama / } \\
\text { NIM }\end{array}$ & $\begin{array}{l}\text { Program } \\
\text { Studi }\end{array}$ & $\begin{array}{l}\text { Bidang } \\
\text { Ilmu }\end{array}$ & $\begin{array}{c}\text { Alokasi Waktu } \\
\text { (jam/minggu) }\end{array}$ & Uraian Tugas \\
\hline 1 & $\begin{array}{l}\text { Leonardo } \\
\text { Luciano } \\
\text { Adolf / } \\
1821 \mathrm{~B} 00 \\
19\end{array}$ & $\begin{array}{l}\text { Ilmu } \\
\text { Kesehatan } \\
\text { Masyarakat }\end{array}$ & Kesehatan & 5 Jam/ Minggu & Ketua \\
\hline 2 & $\begin{array}{l}\text { Putri } \\
\text { Solehana } \\
\text { Pertiwi / } \\
1821 B 00 \\
23\end{array}$ & $\begin{array}{l}\text { Ilmu } \\
\text { Kesehatan } \\
\text { Masyarakat }\end{array}$ & Kesehatan & $5 \mathrm{Jam} / \mathrm{Minggu}$ & Anggota 1 \\
\hline 3 & $\begin{array}{l}\text { Yosefina } \\
\text { Maria } \\
\text { Cinta / } \\
1821 \mathrm{~B} 00 \\
32\end{array}$ & $\begin{array}{l}\text { Ilmu } \\
\text { Kesehatan } \\
\text { Masyarakat }\end{array}$ & Kesehatan & $5 \mathrm{Jam} / \mathrm{Minggu}$ & Anggota 2 \\
\hline 4 & $\begin{array}{l}\text { Sofi Nur } \\
\text { Indahsari } \\
/ \\
1621 B 00 \\
44\end{array}$ & $\begin{array}{l}\text { Ilmu } \\
\text { Kesehatan } \\
\text { Masyarakat }\end{array}$ & Kesehatan & $5 \mathrm{Jam} / \mathrm{Minggu}$ & Anggota 3 \\
\hline
\end{tabular}




\section{SURAT PERNYATAAN KETUA PELAKSANA}

Yang bertanda tangan di bawah ini :

Nama

NIM

Program Studi

Instansi

: Leonardo Luciano Adolf

: 1821B0019

: Ilmu Kesehatan Masyarakat

: STIKes Surya Mitra Husada Kediri

Dengan ini menyatakan bahwa proposal PKM - Penelitian saya dengan judul: "EFEKTIVITAS DAUN WARU (HIBISCUS SEBAGAI ALTERNATIF DETERGEN YANG RAMAS TILIACEUS L.) yang diusulkan untuk tahun anggaran 2019 adalah pernah dibiayai oleh lembaga atau sumber dana lain.

Bila mana di kemudian he

ketidaksesuaian dengan pernyataan dan diproses sesuai dengan ketentuan yang seluruh biaya yang sudah diterima ke kas negara. sebenar-benarnya.

Demikian pernyataan ini dibuat dengan sesungguhnya dan dengan

Mengetahui,

Ketua Prodi Ilmu Kesehatan Masyarakat, METFRAI
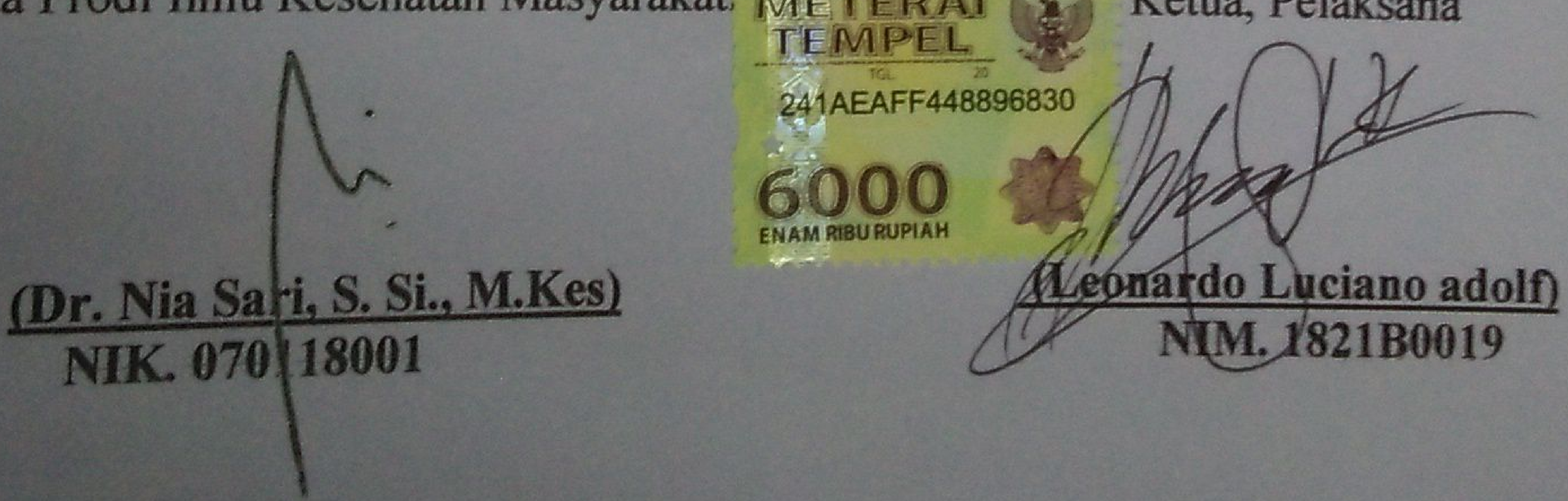